\title{
6 Economy, greed, and liberation theology
}

\section{A critique from a border location in India}

\section{Atola Longkumer}

For those who want the world to remain as it is have already acceded to its self-destruction and, consequently, betrayed the love of God and its restlessness before the status quo.

Dorothee Sölle ${ }^{1}$

How then shall we understand the cross? Not as a death required by God in repayment for sin, but as an event of divine love whereby the Creator of the world entered into intimate contact with human suffering, sinfulness, and death in order to heal, redeem, and liberate from within.

Elizabeth A. Johnson ${ }^{2}$

\section{Introduction}

An Uncertain Glory is the title of a book on India's recent socio-economic development by the Belgian-born Indian sociologist Jean Dreze and the economist Amartya Sen. ${ }^{3}$ The phrase "uncertain glory" aptly conveys the socio-economic, religio-cultural, and political realities of contemporary India. Even as the authors affirm the recent development and the rapid changes that modern India has experienced, they argue that inadequacies and contradictions are evident across different sectors of India. Supported with convincing statistics concerning the prevalence of crushing poverty and debilitating social conditions of a large percentage of the country's demographic, An Uncertain Glory captures the paradox of modern India. On the one hand, India today is listed among the 20 top economies of the world, ${ }^{4}$ with a global presence and influence, yet, on the other hand, the conditions of abject poverty and the abysmal quality of life for many of its populations is telling of the contradictions and lopsidedness of the modern image of an economic powerhouse of the 21st century. Socio-culturally, the realities of the lived experiences of caste violence, gender discrimination, linguistic divisions, power hegemony, religious exclusivism, and ethnocentric social interactions continue to persist in the so-called secular, democratic, and egalitarian society of modern India. In other words, the social index of the country in general remains dismal. ${ }^{5}$ 
The discriminations and marginalisations are most starkly evident in the communities of the most vulnerable sections of Indian society, rendered victims by multiple factors and complex intersections of caste, religion, region, class, gender, and political landscape. Within the complex and intersecting socio-economic canvas of the country, the Dalits, the Adivasis and the tribal/indigenous ethnic minorities of the Indo-Myanmar regions of India comprise the country's most vulnerable and neglected communities. ${ }^{6}$ In a metaphorical sense, the Adivasi/indigenous communities are located at the boundaries of the nation, fenced out by many forms of borders, not just geographical boundaries.

Premised on the persistence of debilitating poverty and powerlessness of the marginalised, this chapter attempts to engage the rhetoric of egalitarian liberation. Drawing from conditions and experiences of border locations of indigenous/Adivasi people of India, the chapter argues that contextual theologies need to critique the inherent social and cultural hierarchies in particular contexts to be truly liberative and enable flourishing for every member of the community. Culturally sanctioned boundaries that exclude and alienate the vulnerable persist in maintaining the economic and cultural status quo of deep inequality. Inclusive justice continues to be elusive; the chapter will argue that it is possible only when the alleged cultural norms within contexts are exposed, challenged, and overcome, and egalitarian practices are intentionally cultivated.

In what follows, some portraits and vignettes are described to mediate the border locations of marginalised communities in modern India. The next section highlights the rigid web of hierarchy that undergirds the persistent exploitation, making injustice pervasive. Identifying the forces of power, greed, consumption, and routinisation of spirituality forms the following section. The final section of the chapter explores a re-imagination of liberation theology for the common good and flourishing of all. The re-imagination proposes three postures that mark an inclusive way of life: first, a critical remembrance of the Christian mission movement, particularly its complex tradition of engaging in projects of social upliftment; second, a call to revisit the prophetic tradition in order to create a just society; and finally, a reimagination of a mystical spirituality that radically resists the hegemony of the ways of the world. In other words, the theological discourse of liberation and egalitarian visions remains in the form of trendy documents and fashionable ideas without intentional lived practices, which in turn feed the structures of oppressive discriminations that produce and exploit the most vulnerable members of the community.

\section{Frames of border locations in India}

The usage of the term "border" refers to more than a geographical boundary. ${ }^{7}$ Border location describes a state of alienation and peripheral locations demarcated by social and economic forces such as caste and gender. 
For instance, despite the prohibition of caste discriminations by the Indian Constitution, caste hierarchy continues to isolate Dalits and render them the most vulnerable community in the country. ${ }^{8}$

The contradictions, diversities, and multilayered identities that make modern India are most vividly portrayed in the sights encountered in a casual stroll down one of the main streets of any of the metropolitan cities in the country. Crowded with tourists and local shoppers satisfying the modern psyche of indulging the market and its glamour, a regular sight that interrupts the carnivalesque expose of materialism is the beggar in rags. Few would take note of the pleading cry from the beggar for a few spare coins. While the oblivious middle class shoppers can be perceived as possessing some identity, not least their ability to participate in the market economy of buying and acquiring, the beggar can only be perceived as a victim: nameless and powerless. He is probably a victim of redundancy, a migrant from a remote region of the nation, who has suffered misfortunes with regard to health, rendering him helpless; or the victim could be an Adivasi whose ancestral lands were transformed into mining caves; perhaps he is a Dalit, who was ostracised from the village for some caste transgressions. ${ }^{9}$ The paradox of a modern economy with its wealth and poverty continues in the country.

Thachur is a village on the outskirts of the metropolitan city of Chennai and has a sizeable Christian community, but is demarcated clearly along caste divides. Caste divisions and identities remain rigid, even in death. Separate burial sites for each caste group, control of land by the higher caste, and the inhuman feudal structure of land ownership dehumanises landless Dalits as bonded labourers. ${ }^{10}$ Rendered marginalised by caste boundaries, Dalits continue to exist on the borders, marked by exclusion and discrimination.

Another vignette of margins comprising the borders in the country is portrayed in the skewed gender ratio in the country. The drastic consequence of female infanticide and male preference is the millions of missing women in the country. According to the latest census, the gender ratio in some states in the country is as low as 850 females to 1,000 males. ${ }^{11}$ Studies on the consequences of female infanticide estimate that around 63 million girls are missing from the country's population. ${ }^{12}$ The skewed gender ratio has a critical impact on traditional social institutions such as marriage. Media reports from Eastern India describe the practices of brothers "buying" one bride to share between them from the impoverished Adivasi communities of the region, because of scarcity of women in the community. ${ }^{13}$

The rapid changes initiated by the liberalisation of the economy in India included transformation of traditional spaces and practices, and development of infrastructures in sync with a modern lifestyle characterised by consumerism. These changes created significant need of labourers across different sectors of the economy, ranging from unskilled labourers to skilled workers who could adapt to a global standard of service and professionalism. Migration of labourers from the remote, neglected, under-developed, 
impoverished regions to the metropolitan cities became a reality of the late modern period in India. ${ }^{14}$ The movement of people into the centre of economy and power brought with it challenges to different aspects of Indian society, not least in the socio-cultural dimension. While India is quintessentially a pluralistic nation, with diverse identities at different levels, the communal tensions between diverse religious and linguistic groups have remained a reality and have manifested in sporadic incidents of communal violence. ${ }^{15}$

Another persistent practice of exploitation in the country is that of housemaids. As the middle class grows, along with the invariable demands of a liberal economy on the time and freedom of professionals, there is a growing need for domestic maids to assist in chores ranging from childcare to housekeeping. This need is fed by exploiting the existing socio-cultural structure of discrimination, whereby young women (mostly impoverished and illiterate) from the Adivasi communities are lured to the city to serve as house-maids. Unorganised and unprotected, these women remain one of the most vulnerable groups of citizens, risking verbal/physical/sexual abuse and inhumane treatment, and often being underpaid. ${ }^{16}$

These vignettes are some portraits that constitute a collage of border locations in the so-called growing economy of India. Undoubtedly, the economic growth of India in recent years cannot be denied, but its GDP remains low and the growing wealth has not benefitted the most vulnerable sections ${ }^{17}$ of the country's population. Related to the economic disparity is the persistence of socio-cultural hierarchies such as those of caste, gender, and ethnicity. With a complex web of intersections of caste, ethnicity, gender, and economic class, the demographics that comprise the most vulnerable continue to be victimised, exploited, and marginalised.

The selected portraits therefore demonstrate that oppressive, exclusive, hostile borders and demarcations are created and maintained by the rigid religious and economic conditions of the country. If geographical boundaries isolate and delineate between insider and outsider, religious and economic boundaries produce margins, characterised as the "other", that is, strange and alien. As borders signify marginality, to inhabit the edges of society, removed from the centre of privilege and axis of power to reside in borders, is to exist in uncertainty and vulnerability, ignored and isolated. ${ }^{18}$ Jean Dreze and Amartya Sen rightly attribute the state of "continued disparity between the lives of the privileged and the rest" and the "persistent ineptitude and unaccountability in the way the Indian economy and society are organized" 19 as factors in the persistence of peripheral locations for many in the country.

The alienations and disparities are not confined to society at large; these conditions are prevalent in ecclesial spaces. For instance, despite the progress made in the participation of women in ministry and theological education, women across different socio-cultural groups in the country face discrimination in the community of faith. Sexist attitudes derived from a 
"kyriarchal" ${ }^{20}$ theology persist, often manifested in language, behaviour, and church practices. Caste tensions and divisions remain a stark reality inside the church. ${ }^{21}$ Robust scholarship and organic activism of Dalit, Adivasi, and gender liberation issues have created awareness to some extent; some churches in the country have participated in global ecumenical movements, such as Decade of Churches in Solidarity with Women. However, the recognition and participation of women is making only incremental progress.

\section{Caste, economy, greed, and the making of the vulnerables in India}

Embracing the neo-liberal economy in the last quarter of the 20th century, India has seen rapid transformation from a traditional economy to a liberalised and globalised economy, effecting tremendous changes in some aspects of society. However, the economic growth has not translated into quality of life for all citizens. As illustrated in the preceding discussion, poverty, gender discrimination, caste violence, and ethnocentricism remain challenges across different sections of Indian society. The glaring gap between the wealthy class and the poor is palpably visible in many aspects of life, ranging from access to medical care to basic amenities such as electricity. In the second decade of the millenium, India stands at the threshold of innovation and industrialisation, with a large youth population; however, the threat of the rising religio-nationalism remains a potent reality. The assertion of a dominant religion ${ }^{22}$ in politics and the economy portends further alienation of the marginalised communities such as the Dalits, Adivasis, tribals, and religious minorities.

Writing on the new economic policy that India adopted as part of globalisation and its impact on the Dalits, Manas Upadhyay notes that "Dalits remain poor, illiterate, lack requisite skills for competing in the modern world, enjoy unequal access to productive resources, and remain deeply tied to land and traditional occupations". ${ }^{23}$ A market economy with maximum profit for wealthy corporations has only accentuated the existing marginalisation of the Dalits by way of land acquisition, mechanisation of most production, professionalisation, and concentration of wealth in the hands of the traditional land owners. ${ }^{24}$

India's new economic policy has undeniably brought seismic changes in the standard of living and lifted many from abject poverty; yet, Jean Dreze and Amartya Sen's more realistic analysis of poverty in the country is also shared by Gail Omvedt, who notes only a fractional decline in poverty among the Dalits. ${ }^{25}$

Despite the economic growth, the existing socio-economic hierarchies have remained unchanged and therefore the economic growth has not translated into social progress. As Dreze and Sen caution, "it is extremely important to point to the fact that the societal reach of economic progress 
in India has been remarkably limited". ${ }^{26}$ The economic reforms that tuned the country to the demands of globalisation have not made any "effort to make small producers - small farmers, artisans, fish workers [sic], Dalits, tribals - the focus of the economy growth". ${ }^{27}$ Without measures for social justice for the marginalised communities in the country, an economic policy of finance-capitalism and consumerist production stands only to contribute to the growing inequalities between the powerful and the most vulnerable citizens such as the Dalits, Adivasis, and tribals. The deep social hierarchies that sustained caste injustice, feudal ownership of agricultural land, gendered economic roles, and caste-assigned occupations are some of the rigid conventions compounding the capitalist economy geared toward maintaining economic inequalities.

Analysis of the unchanged socio-economic conditions for the most vulnerable people in the country calls on the liberation movements, such as Dalit and tribal theologies inspired by liberation theology, to continue tenaciously in the struggle to journey towards justice. Felix Wilfred writes,

the radicalness of Dalit theology could be seen also in the way it unmasks the traditional social constructs of purity and pollution, high and low, and its restlessness regarding the ideological justifications, be it in the society or within the Christian communities. ${ }^{28}$

Inspired by liberation theology, movements and theologies of the people were fervently initiated, disrupting the dominant discourse and drawing attention to the oppressive structures of the de facto representative sociocultural traditions. ${ }^{29}$ Drawing global attention, enlarging the lens and shifting the emphasis, these liberation theologies in the country have changed the discourse and undoubtedly created awareness among the people.

It must, however, be emphasised that critical observations of the marginalised communities reveal parallel chaos and injustices within the communities. In general, caste identities and collective cohesion persist, tribal parochialism exists, and gender roles remain unchallenged on many levels, particularly within the ecclesiastical structures.

While reasons for such a stagnation of the movement of liberation vary, an underlying causal factor might lie within the traditional and limited understanding of Christianity itself. On the one hand, Christianity was understood as seeking to accommodate the good of Sanskritic Hinduism, and on the other hand, as being limited in its scope to salvation alone, without social critical engagement. Both of these understandings of Christianity were muted in challenging the social and economic marginalisations of the poor and the dispossessed. ${ }^{30}$ The force of the market and consumerist pressure is another reason why individuals have tacitly given in to the idol of mammon. ${ }^{31}$

Given the persistence of marginalisation and socio-economic disparities, compounded by the rise of a political class aligned to a dominant 
religion, a critical revisiting of the liberation movement is necessitated. From the border locations of vulnerabilites in India, crucial questions of power, Christian prophetic traditions, Christian missions, and Christian spiritualities emerge. Answering the questions and accounting for a just world entails explorations of the inherent Christian theological vision of righteousness manifest in a just and inclusive creation. In the following section, I shall explore a critical re-imagination of liberation theology, engaging three dimensions of Christianity: mission, prophetic tradition, and mystical spirituality.

\section{A critical re-imagination of liberation theology in India}

Liberation theology has its roots in the socio-economic contexts of Latin America in the 1970s. The beginning of this revolutionary movement was in Medellín, Colombia, at the Second General Conference of Latin American Bishops in September 1968. ${ }^{32}$ The conference at Medellín was preceded and inspired by the writings of Gustavo Gutiérrez, through seminal presentations; his was a theology rooted in Scripture that took experience as crucial for social transformation. ${ }^{33}$ Gutiérrez's foundational text, Theology of Liberation, is cited as the kernel of liberation theology, and the famous conference at Medellín "legitimate[d] a new kind of Catholic radicalism in Latin America that could now cite the official statements of the bishops in support of their arguments". ${ }^{34}$

Anchored in the Roman Catholic church in Latin America, ${ }^{35}$ liberation theology articulated a demand for liberation from the dominant Eurocentric theology amidst the crushing exploitation of a capitalist system. Liberation theology in its seminal form sought the freedom and welfare of the poor peasants and labourers caught in the complex web of economic development characterised by industrialisation and the profiteering of multinational corporations. According to some perspectives, the conference in Medellín was inspired by Vatican II and its call for a church that was more engaged with the people; furthermore, the leadership of Dom Helder Camara was significant in directing the church to serve the poor and foster greater dialogue between the industrial and undeveloped worlds. ${ }^{36}$

Leonardo Boff also locates the beginning of liberation theology "[at] Medellín (1968) [as] the Church began to walk with the underworld of poverty and misery that characterised the Latin American continent, then and now. By the power of the Spirit, Latin American pastors made a courageous option for the poor and against poverty", implementing

a practice of integral liberation: not only from our personal and collective sins, but from the sins of oppression, the impoverishment of the masses, discrimination against indigenous people, contempt for people of African descent, and the domination of women that men have practiced since the Neolithic age. ${ }^{37}$ 
In other words, the liberation theology that had its origins in the Latin American context unmasks the many forms of oppression beyond the immediate environs of Latin America.

The basic question underlying liberation theology is "how to be Christians in a world of destitution". ${ }^{38}$ Upon this foundational question, Leonardo Boff and Clodovis Boff anchored the rationale, urgency, and praxis of liberation theology kindled by the immense suffering of the poor. In its fundamental content, liberation theology was a theological cry with the vulnerable poor, rendered victims by different powerful forces such as free-market capitalism, landowners, and privileged elites. The Boffs write, "liberation theology can neither exist nor be understood" without sharing the suffering of the poor. ${ }^{39}$ Therefore, liberation theology has its genealogy in a moment of crisis for people of faith, facing extreme poverty and destitution; in such a context, the question arises of how to live out the belief in a compassionate God, who suffered for the "sins" of the world. A confident theology of the sovereignty of God was shaken when confronted with wilful injustice done to the poor by the selfishness of the few. ${ }^{40}$ The option for the poor becomes a reality when the proponents of liberation theology struggle in solidarity with the poor. In the solidarity with the exploited and the vulnerable, the witness to the crucified Christ translates into realities of life.

According to the Boffs, the objective of liberation theology - to gain dignity and freedom for the exploited poor - required a "strategy of liberation" wherein the oppressed come together, and through a process of conscientisation arrive at an understanding of the oppressive structures and act together as an organised movement. ${ }^{41}$ Liberation theology, therefore, is a collective praxis sharing a common vision of a just system; as summarised by Christopher Rowland, liberation theology springs from a life engaged in struggles and deprivation, and "from the insights of those men and women who have found themselves caught up in the midst of that struggle, rather than being evolved and handed down to them by ecclesiastical or theological experts". ${ }^{42}$

As a collective movement, Latin American liberation theology in the last quarter of the 20th century went beyond its immediate contexts, inspiring other people's movements for freedom from different forms of domination and oppression. In India, liberation theology provided the vision, the primary framework, and the initial vocabulary to Dalit, tribal, and various feminist liberation theologies. ${ }^{43}$

Rowland writes on the continuing task of liberation theology that

the seeds of hope have been sown. Yet everywhere the situation which prompted liberation theologians to write and explore a different way of engaging in theological reflection from what had become the norm, has not improved. In many parts of the world it has become worse, and it is this continuing context which prompts a continuing need for the kind of theological engagement we find in liberation theology. ${ }^{44}$ 
Indeed, from the perspective of marginalised communities in India, despite the decades of theological articulation and the variety of ecclesiastical programmes initiated towards inclusive justice for the marginalised and excluded in the country, the conditions of deprivation and discrimination persist. Exclusion is manifested in different forms in the country: caste, tribal identity, gender, and economic class. An underlying factor in marginalisation is the unchallenged structures of cultural practices that are normalised. In deeper analyses, there is a disconnect between rhetoric and the practices of daily living. The persistent experiences of discrimination in relation to caste, gender, and class identities, particularly of marginalised members who comprise the border location, beg the question of why victimisation of the vulnerable continues, despite the legal prohibition and decades of social conscientisation. The option for the poor requires the dismantling of the structures that produce the poor, and deconstruction of the norms that sustain exclusive hierarchies. The rigid and normalised structures are more than the capitalist economy; they include caste practices, gender privileges, and inherent ethnocentric biases. The discourse of liberation theology is essentially a discourse of inclusive justice that provides the impulse for transformational praxis in daily ways of living.

In the following section, the chapter will explore three modes of continuing the liberation movement as inspired by liberation theology as a way of answering the basic question of liberation theology: "how can we proclaim the freedom inherent in a loving God manifested in Jesus of Nazareth?"

\section{Remembrance of Christian mission and human dignity}

Christian mission and liberation theology make an ambivalent pair. From a certain reading of Christian mission, often the dominant perspective, the history, practice, and theology of Christian mission is criticised as inherently intertwined with the globalised market economy. ${ }^{45}$ While to some extent the multifaceted work of Christian mission enabled the expansion of the market economy, the situation is arguably more complex than a simplistic pairing of colonial commerce and Christianity. Nonetheless, the subjugation of local cultures, the intense professionalism, privatisation of wealth, and transfer of modes of industrialisation are seen as consequences of Christian mission. Liberation theology, on the other hand, is a critical response to a theological view that is predominantly Eurocentric in its ambivalence towards globalisation. Christian mission evaluated from a limited perspective arguably posits a critical challenge to the project of liberation theology, for in its essence, Christian mission traced to the eighteenth and nineteenth century emanating from the West did possess a fundamental theology that established practices, structures, theology, and teleology characterised by progress and power often measured in terms of accumulated wealth. In the following list, Brian Stanley summarises the five basic rationales that 
undergirded the practice of Christian mission from the West in the 18th and 19th centuries:

- A ... belief that non-Western peoples were "heathens", lost in the degradation of sin and in need of salvation through the gospel of Christ.

- A ... tendency to dismiss other religions either as "heathen idolatry" or as ... superstitions ... devoid of any trace of the presence of God.

- A belief in the manifest superiority and liberating potential of Western "civilisation", in both its intellectual and technological aspects.

- Confidence in the regenerative capacity of rational knowledge ... linked to Christian proclamation.

- An assumption that the Christian message was addressed principally to individuals. ${ }^{46}$

Despite being more complicated, Christian mission's shared legacy with imperialism and its operational structures drawn from an attitude of assumed superiority justifying the subjugation of cultures does impede the argument for Christian mission's project of freedom and liberation in oppressive socio-economical contexts. Therefore, a return to Christian mission in critical engagement with an unfinished agenda of liberation theology might provoke incredulity, particularly in the context of India, with its many forms of malaise, not least the discrimination against those of low caste, Adivasi, women, and other minority communities.

That Christian mission history and practice has inevitably shared imperialistic structures cannot be disputed. However, it is crucial to recognise the complexity of Christian mission in its project across varying historical periods and disparate organisations and diverse theological understandings expressed through different ways of working. Put simply, Christian mission's legacy is complex and multifaceted, especially as unfolded in the historical and contextual realities of India. ${ }^{47}$

During the heyday of the Western missionary movement, Christian mission in India saw a variety of mission organisations and activities. Without elaborating on the details, it is common knowledge that translation of vernacular languages, dissemination of knowledge, printing newspapers, establishing educational institutions and hospitals, forming women-focused programmes such as the Zenana mission, organising agricultural institutions to enhance the rural economy, ${ }^{48}$ and nascent settlements for landless lower castes ${ }^{49}$ were all conduits of Christian mission.

Naturally, the socio-economic activities of Christian mission were secondary to the primary objective of evangelistic zeal to preach the good news and establish communities adhering to Christianity. While this is generally indisputable, to ignore the commitment of Christian mission to share the features of the perceived "good life" characterised by "modern" aspects of progress, and organised activities contributing to human dignity and flourishing, would amount to a rigid ideological stance. 
The criticism against Christian mission in toto was most vehement and pronounced in the late-20th-century post-independence period. ${ }^{50}$ Despite the critical denouncement, to re-evaluate Christian mission and its socioeconomic activities that express commitment to justice and human dignity is vital given the persistence of discrimination, inequalities, accumulation of wealth, ecclesiastical excesses, and gender exclusion in contemporary India.

Despite initial resistance from home mission boards and other limitations, women missionaries were instrumental in connecting to local (native) women and their circumstances, which were curtailed by cultural conventions. The phenomena of Bible Women, ${ }^{51}$ female education, reforms of socio-cultural rituals, and hospitals are directly related to the work of women missionaries in the modern missionary movement. From the many historical records, the example of Helen Barrett Montgomery (1861-1934) will suffice, a Baptist who championed women's missionary engagement in the "Eastern Lands" and the cause of progress for women. She was a child of her times, yet a visionary for women's liberation, as the following words from her speech to the gathering of the Third Baptist World Congress, at Stockholm in 1923, illustrate:

Jesus Christ is the great Emancipator of woman. He alone among the founders of the great religions of the world looked upon men and women with level eyes, seeing not their differences but their oneness, their humanity. He alone put no barriers before women in his religious teaching, but promulgated one law, equally binding upon men and women, opened one gate to which men and women were admitted upon equal terms. ${ }^{52}$

Collobaration in establishing modern socio-economic structures and preparing agents to partake in the modern structures are both Christian mission legacies..$^{53} \mathrm{~A}$ balanced analysis, therefore, will include the aspects of Christian mission that contribute to the flourishing of the good life for every member of the community. Remembering Christian mission's commitment to human dignity shares a common vision with today's call for socio-economic justice in an inclusive society. In a growing economy such as India, with lopsided developments and contradictions rendering millions vulnerable, Christian mission's fundamental commitment to uplifting every individual across the diverse socio-cultural contexts is even more urgent. The foundational principle of liberation theology in its option for the poor finds a parallel commitment in a Christian mission that understands that proclamation of the Gospel includes social justice in a holistic flourishing of creation. ${ }^{54}$

\section{Reclaiming a prophetic voice for justice}

The prophets in the Hebrew Scripture announced the kingdom of God characterised by a just society. The denunciation of abuse of power, misplaced 


\section{2}

sacrifice, and unfaithfulness of the people to Yahweh sprang from a deep sense of justice that included economic justice. Amos, Isaiah, Micah, and Jeremiah all have passages that vehemently condemn greed, abuse of power, exploitation of the poor, and ritualistic practices that are meaningless. ${ }^{55}$ Michael Barram underlines the passionate language Amos employed to denounced those who "trample the head of the poor into the dust of the earth and push the afflicted out of the way" (Amos 2:7, NRSV). ${ }^{56}$ In brutalising the most vulnerable among them, the Israelites displayed their arrogant neglect of the covenantal code as a people. ${ }^{57}$ Explaining the central message of the prophet Isaiah, Barram writes,

The people are out of practice with justice; they need a radical reorientation in their thinking, accompanied by drastically different conduct. To "seek justice" in a covenantal context is to foster a holistic community of interdependent relationships in which all, including the most vulnerable, flourish consistently. ${ }^{58}$

In denouncing the injustices, the prophets were announcing the call to return to righteousness and liberation as God intended for his people.

Being convinced of the vision of God for a just society, prophets are individuals who announce freedom for victims of oppressive structures - social, political, and economic - and the destruction of religiosities devoid of meaning. The prophetic tradition of the Hebrew Scripture has modelled a way for individuals and communities to seek justice and the good of the people with passionate commitment springing from an unsettling aversion to injustice that renders people vulnerable. Drawing from the prophetic tradition of the Hebrew Scripture, individuals and movements through history have taken up struggles against powerful structures of self-interest, risking hostility, alienation, and life itself.

Liberation theology agrees with the prophetic tradition in seeking the liberation of people who are rendered vulnerable victims of dominant structures such as the profit-seeking economic system of the late 20th century. Liberation theology addresses how to proclaim a God who is revealed as love in a world of poverty and exclusion, and how to proclaim the "Gospel of liberation". ${ }^{59}$ To proclaim the love of God as manifest in the life and work of Jesus is to proclaim liberation. To proclaim the love of God is to proclaim the kingdom of God. But amidst debilitating poverty and marginalised powerless, proclaiming the kingdom of God that is marked by inclusive love is meaningless unless the causes and roots of oppression and exploitation are destroyed. ${ }^{60}$

The task of theology as a prophetic articulation of the central message of the Gospel of freedom from destructive self-centredness also finds strong emphasis from Dorothee Sölle, who categorically states, "The gospel has to do with freedom for all, or more precisely - since the reality of oppression remains in the picture - its essence is the liberation of all". ${ }^{61}$ The liberation 
and freedom of the individual is interconnected with the liberation and freedom of the collective community. Faith as nurtured by the Gospel posits the liberation of all, not the isolated event of an individual act. ${ }^{62}$ Sölle summarises this, saying that theology cannot be mere theoretical abstraction, but is "a praxis of love that has value only as an apparent consequence of faith, because it conceives truth not as knowledge, but as fulfillment of life". ${ }^{63}$

Theology that is action-oriented in its solidarity with the vulnerable reclaims the prophetic traditions amidst the challenges, and nurtures the passion to interrupt structures that feed systems of exploitation. Borrowing the term "interrupting" from the theologian Johann Baptist Metz, Matthew A. Shadle proposes an interruption of capitalist forms of economy. According to Shadle, interrupting capitalism is " 'breaking into' the economy, adopting practices of solidarity that have the potential to transform the economy" ${ }^{64}$ While interrupting capitalism is not synonymous with dismantling the global economy, it calls Christians' attention to the economic conditions of the present age and underlines the imperative for Christians to proactively engage in transforming the global economy, drawing from the traditions of justice and practices of generosity inherent in the faith. To interrupt capitalism in its self-destructive drive today is to demonstrate an alternate reality of solidarity rather than hopelessness and despair. ${ }^{65}$

Prophetic pronouncements against injustice interrupt the status quo and declare an alternative reality. Through the prophets, God interrupts and shifts the priorities to the marginalised. Theological interruptions such as Dalit theology and tribal theology ${ }^{66}$ in the Indian context have challenged the traditional theological orientations. Felix Wilfred astutely captures the significant impact of Dalit theology in this way: "Dalit theology has shaken the traditional way of pursuing theology by drawing our attention to the experience of the most oppressed and marginalized groups in the Indian society" ${ }^{67}$ Further, to persist in the struggle for freedom for the many victims inhabiting border locations in India entails reclaiming the prophetic tradition in announcing the alternative reality that is the kingdom of God.

\section{Mystical spirituality for collaborators towards justice}

Critical re-imagination of liberation theology amidst the demanding challenges of modern India also calls for a spirituality that is marked by a deep, mystical relationship with the sacred. A radical belief sustained by confidence in sharing an interdependent relationship with God is sufficient for engaging in resisting mammon and its debilitating structures. In sharing the solidarity of the struggle with the poor and the marginalised, in sharing the vision of a just inclusive humanity, the ordinary people become collaborators with God. They become agents of transformation and form the bridge between the righteousness of God and a humanity in need of reconciliation. The agents for transformation become the conduit for God's passionate justice to be realised. Collaborators are sustained by a mystical spirituality that 
holds humanity and the divine together - a mystical spirituality marked by immersion in a radical denouncement of the ways of the world and complete surrender to the ways of God.

Interrupting the rigid hierarchies entails an encounter with the divine that illuminates a deeper understanding of the faith - an understanding that faith is meaningful only when expressed in praxis. ${ }^{68}$ The web of hierarchies and scaffold of oppressive networks as designed by an economic policy biased towards accumulation, excess profit, and extreme consumerism can only be resisted with a lifestyle rooted in the unfathomable wisdom of God. Because of its realisation in the absoluteness of God in all things and the interconnectedness of all creation, mystical spirituality enables us to resist the distractions of mammon and of the powers of the world. ${ }^{69}$

Dorothee Sölle realised this truth, that seeking an inclusive community, yearning for peace, hungering for justice, and desiring healing in the world required a mystical dependence on God. The search for the liberation of humanity could only be sustained by balancing a prophetic zeal with a passionate longing for God, because human liberation included God in the journey as well as in the destination. ${ }^{70}$ Solidarity with the vulnerable unveils God's own pain at humanity's selfishness; as Sölle writes,

suffering does not necessarily separate us from God. On the contrary, it may actually put us in touch with the mystery of reality. To follow Christ means to take part in his life ... Compassio in this sense ... arises in the immediacy of innocent suffering and from solidarity with those who have to bear it. ... Without compassio, there is no resurrection. ${ }^{71}$

A vision and deliberate lifestyle that embraces the suffering and the limitations experienced by the marginalised poor declares in effect the shallowness of the dominant powers, and in participating in the struggle for justice expresses itself "in mystical defiance" that suffering will be overcome through the unfathomable love of God only comprehended by those who share the deep knowledge of God's own self. ${ }^{72}$

The enormous challenge for justice calls for a spirituality deeply grounded in God; as Elizabeth A. Johnson writes, "[w]ithout the incomprehensible God as the horizon and ultimate fulfillment, the human project itself would meet an impenetrable limit such that the human spirit would shut down, having no further depths of knowledge, or love to plumb". ${ }^{73}$ Therefore, a prophetic theology of interruption can only be sustained by a mystical relationship with the ineffability of God, because the human mind is incapable of grasping the reality of the divine mystery that desires the good of all creation. ${ }^{74}$

While mystical spirituality might indicate an interiorised spirituality that is oblivious to the external environs, and therefore might seem untenable for a liberation theology, a prophetic interruption calls for an intense spirituality marked by ineffable trust in God as proclaimed in the good news 
of Christ received by faith. In the context of deep misery and faced with the despair of contemporary socio-economic realities, humanity can only entrust its existence to the holy mystery of God, full of wisdom and unfathomable love. ${ }^{75}$

\section{Conclusion}

This chapter has presented a portrait of the global situation today as manifested in a particular context, India, where there is immense marginalisation, made vulnerable by an economic system beholden to wealth and profit. Such an economic system is further sustained by existing rigid socio-cultural structures of caste, class, race, and gender. An economic system of profitmaking poses an immense threat to the natural environment, as evident in the tremendous changes in natural seasons and habitats across the globe. What is distinct about the contemporary depraved situation of extreme inequality is its reach around the globe. Furthermore, the existence of extreme inequality and insecurity amidst the tremendous wealth and progress of humanity points simply to the greed of a few. A commitment to an inclusive and just way of life is required to ensure the flourishing of all creation.

In the context of persistent marginalisation in India, the chapter has proposed three practices that have enduring relevance in movements striving for justice and the wellbeing of society. The immense number of the victims of the socio-economic structures necessitates a critical remembrance of Christian mission's commitment to realisation of human dignity and freedom as integral to the Gospel. Furthermore, a critical recalling of liberation theology in the country also entails a prophetic passion to persist and continue the initial movements of liberation, such as Dalit, tribal, and feminist theologies in the country. Finally, the chapter underscored the centrality of a mystical spirituality that nurtures the journey of struggle and solidarity with the marginalised. In its essence, a mystical spirituality draws its confidence from the deep relationship and union with the mystery of the divine, whose grace upholds all of creation.

In the task for theology to continue to interrupt oppressive norms and to articulate the truth of the Gospel that is inclusive, the following words from Jon Sobrino are helpful:

what takes my breath away is when people keep saying that liberation theology has gone out of fashion. Poverty is increasing in the Third World [sic], the gap between the rich and the poor countries is widening, there are wars - more than a hundred since the last world war and all of them in the Third World [sic]. Cultures are being lost through the imposition of foreign commercial cultures. ... Oppression is not a fashion. The cries of the oppressed keep rising to heaven ... more and more loudly. God today goes on hearing these cries, condemning oppression and strengthening liberation. Anyone who does not grasp this has not 
understood a word of liberation theology. What I ask myself is what theology is going to do if it ignores this fundamental fact of God's creation as it is. How can a theology call itself "Christian" if it bypasses the crucifixion of whole peoples and their need for resurrection, even though its books have been talking about crucifixion and resurrection for twenty centuries? Therefore if those doing liberation theology are not doing it well, let others do it and do it better. But someone must keep on doing it. And for the love of God let us not call it a fashion. ${ }^{76}$

The good news as expressed in the work and life of Jesus of Nazareth gives life, and not to share this faith is to betray the love of God for every creature, ${ }^{77}$ and would be to withhold the kingdom of God marked by healing, life, joy, and liberation ${ }^{78}$ that Jesus Christ inaugurated.

Liberation theology emerged in the context of tremendous economic changes in Latin America, and the theological articulations and the sacrifices of the pioneers of liberation theology went beyond this, inspiring many other people's movements of liberation. Given the global realities of economic inequalities and rise of exclusivism manifested in violent resistance to the other, liberation theology that articulates the love of God and its intentional option for the poor and the marginalised is even more urgently needed today.

\section{Notes}

1 Dorothee Sölle, The Silent Cry: Mysticism and Resistance, trans. Barbara and Martin Rumscheidt (Minneapolis: Augsburg Fortress Press, 2001), 3-4.

2 Elizabeth A. Johnson, Abounding in Kindness: Writings for the People of God (Maryknoll, NY: Orbis Books, 2015), 13.

3 Jean Dreze and Amartya Sen, An Uncertain Glory: India and its Contradictions (Princeton, NJ: Princeton University Press, 2013).

4 Available data from global economic statistics in 2019 positioned India among the top economies in the world, despite the vast task of providing a sustainable livelihood, modernised infrastructure, and quality of life to the millions living in precarious poverty. See www.worldbank.org/en/country/india/overview, and www.imf.org/en/Countries/IND\#countrydata, accessed November 11, 2019. Incidentally, more discouraging is data that indicates India's position in the Global Hunger Index 2019; India is ranked 102nd out of 117 countries, behind Myanmar (rank 69), Pakistan (rank 94), Nepal (rank 73) and Bangladesh (rank 88). www. thehindu.com/news/national/global-hunger-index-2019-india-ranked-lower-thannepal-pakistan-bangladesh/article29714429.ece, accessed November 11, 2019.

5 The cache of data provided by Jean Dreze and Amartya Sen parallels other sources; for instance, the poverty deduction data provided by the World Bank indicates minuscule change in the corresponding years of growth in the GDP of the country; see http://povertydata.worldbank.org/poverty/country/IND, accessed August 3, 2019.

6 The terms "tribal" and "Adivasi" are gaining more currency in their usage to describe the communities that are outside the Indic/Hindu traditions. Sharing broad features more akin to those of other indigenous people, the Adivasi and 
tribals are people with distinct oral languages and shamanic religiosity who inhabit the remote regions in the country. The Indian Constitution categorises them under the term Schedule Tribe (ST). For more detailed discussion, see Virginius Xaxa, State, Society, and Tribes: Issues in Post-Colonial India (Noida: Pearson, 2008); Nandini Sundar, ed., The Scheduled Tribes and Their India: Politics, Identities, Policies and Work (Delhi: Oxford University Press, 2016); Meena Radhakrishna, ed., First Citizens: Studies on Adivasis, Tribals, and Indigenous Peoples in India (Delhi: Oxford University Press, 2016).

7 The concept of "border" is employed here to frame conditions of binary divide and as a metaphor to delineate the locations of marginality, which are not just limited to spatial boundaries; for instance, a lucid discussion on the implications of the term within the discipline of critical education is presented by Henry A. Giroux, Border Crossings: Cultural Workers and Politics of Education (New York: Routledge, 1993), 21-22. A Christian mission perspective of border crossing is discussed by Peter C. Phan, who highlights three functions of borders as barriers and identity markers. Peter C. Phan, "Crossing the Borders: A Spirituality for Mission in our Time from an Asian Perspective," accessed November 11, 2019, https://sedosmission.org/old/eng/phan_2.htm.

8 A recent publication provides a comprehensive context and catalogue of violence against Dalits and Adivasi in the country. See Martin Macwan, ed., Bhed-Bharat: An Account of Injustice and Atrocities on Dalits and Adivasis 2014-2019 (Ahmedabad: Dalit Shakti Prakashan, 2018).

9 According to reported data from the National Crime Records Bureau, there were a total of 119,872 incidents of atrocities on Dalits in three years, 2014-2016. See Martin Macwan, ed., Bhed-Bharat.

10 S. Dorairaj, "Caste Divide," Frontline: India's National Magazine, February 25, 2011, accessed May 15, 2019, https://frontline.thehindu.com/static/html/fl2804/ stories/20110225280403800.htm.

11 http://censusindia.gov.in/Census_Data_2001/India_at_glance/fsex.aspx, accessed May 15, 2019.

12 Priyanka Pulla, "What are the Consequences of India's Falling Sex Ratio?" The Hindu, March 3, 2018, accessed May 15, 2019, www.thehindu.com/sci-tech/ health/what-are-the-consequences-of-indias-falling-sex-ratio/article22920346. ece. See also Manasi Gopalakrishnan, "Female Feticide in India - a Paradox of Development?" Deutche Welle, August 1, 2019, accessed November 7, 2019, www.dw.com/en/female-feticide-in-india-a-paradox-of-development/a-49852825.

13 Haryana Kotla, "Seven Brothers," The Economist, April 7, 2011, accessed May 15, 2019, www.economist.com/asia/2011/04/07/seven-brothers.

14 For a recent study on migration of northeasterners to the cities, see Bengt Karlsson and Dolly Kikon, "Way Finding: Indigenous Migrants in the Service Sector of Metropolitan India," South Asia: Journal of South Asian Studies 40, no. 3 (2017): 447-64.

15 Among the plethora of texts on the communal tension and violence, an excellent study highlighting the modern roots may be found in Martha Nussbaum, The Clash Within: Democracy, Religious Violence and India's Future (Cambridge, MA: Harvard University Press, 2007). Incidentally, the recent rise of the aggressive Hindu-right political party Bharatiya Janata Party (BJP) has seen growing violence, such as lynching, against minority communities.

16 N. Neetha, "Urban Housekeepers from Tribal Homelands: Adivasi Women Migrants and Domestic Work in Delhi," in First Citizens: Studies on Adivasis, Tribals, and Indigenous Peoples in India, ed. Meena Radhakrishna (Delhi: Oxford University Press, 2016), 219-32, discusses the impact of the changes in modern economy in the communities of Adivasi, most evident in the migration 
of Adivasi women to cities to work as domestic help. She writes, "The movement of women from Adivasi pockets to cities for domestic work goes back to the late 1970s. It witnessed an unprecedented increase in the 1980s and more so in the 1990s. The major source areas for Adivasis women are the states of Jharkhand, Chhatisgarh, Odisha, Assam, and West Bengal. The cities such as Delhi, Mumbai and Bengaluru are the receiving places for Adivasis migrants" (230).

17 For example, the economic deprivations of the Adivasi population across the country continue, compounded by mismanagement of the digitisation programs designed to enable efficient distribution of public services such as ration cards. Recent media reports of Adivasi (tribal/indigenous people) in the state of Jharkhand dying of starvation only confirms these grim economic realities; see Shiv Sahay Singh, "Death by Digital Exclusion? On Faulty Public Distribution System in Jharkhand," The Hindu, July 13, 2019, accessed November 11, 2019, www.thehindu.com/news/national/other-states/death-by-digital-exclusion/arti cle28414768.ece.

18 Jooseop Keum, ed., Together Towards Life: Mission and Evangelism in Changing Landscapes (Geneva: WCC Publications, 2013), 15; herein the mission document of the World Council of Churches spells out the conditions of margins as "exclusion from justice and dignity"; by contrast, those occupying the centre are those "having access to systems that lead to one's rights, freedom, and individuality being affirmed and respected".

19 Dreze and Sen, Uncertain Glory, 11.

20 Elisabeth Schussler Fiorenza coined the neologism "kyriarchy" to point out the complex and intersecting multiplicative social structures of oppression that go beyond patriarchy - male-centric domination. Derived from the Greek word "kurios", the neologism kyriarchy redefines the structures of domination. Developed within the area of biblical interpretation, the concept of kyriarchy is adopted in feminist critical theory to describe the web of dominance and interconnected oppressive structures. See Elisabeth Schussler Fiorenza, Rhetoric and Ethic: The Politics of Biblical Studies (Minneapolis, MN: Fortress Press, 1999), 5-6.

21 A. P. Nirmal, "Toward a Christian Dalit Theology," in Frontiers in Asian Christian Theology: Emerging Trends, ed. R. S. Sugirtharajah (Maryknoll, NY: Orbis Books, 1994), 27-40; John Webster, Dalit Christians: A History (New Delhi: ISPCK, 1992); James Massey, Indigenous Peoples: Dalits: Issues in Today's Theological Debate (Delhi: ISPCK, 1994).

22 The categories of both religion and modern Hinduism need clarifications underscoring the complex working of power in controlling and solidifying the trajectory of modern knowledge. For detailed discussion on the topic, see Geoffrey Oddie, Imagined Hinduism: British Protestant Missionary Constructions of Hinduism, 1793-1900 (New Delhi: Sage Publications, 2006); Richard King, Orientalism and Religion: Postcolonial Theory, India and the Mystic East (London: Routledge, 1999); Michael J. Altman, Heathen, Hindoo, Hindu: American Representations of India, 1721-1893 (Oxford: Oxford University Press, 2017). Altman discusses the role of American university programs in contributing to the category and the study of Hinduism as it is known today.

23 Manas Upadhyay, Globalization and Dalits: Still Lagging Behind (New Delhi: Serials Publications Private Ltd., 2017), 88.

24 Sundar, ed., The Scheduled Tribes and Their India, 31-33.

25 Gail Omvedt, "Economic Policy, Poverty and Dalits," in New Economic Policy and Dalits, ed. P. G. Jogdand (New Delhi: Rawat Publications, 2000), 38-57.

26 Dreze and Sen, Uncertain Glory, 8; we might consider, for instance, the dismal situation regarding power (electricity). There are frequent outages daily for those who have access to electricity, along with 200 million who do not have electricity. 
27 Omvedt, "Economic Policy," 56.

28 Felix Wilfred, Margins: Site of Asian Theologies (Delhi: ISPCK, 2008), 61.

29 One of the pronounced shifts is the intervention in the theological conversation dominated by brahminical texts and worldviews.

30 Gail Omvedt, “The Doubly Marginalised," Seminar 602 (2009): 70-75, accessed May 21, 2019, https://eprints.soas.ac.uk/17278/1/2009/602/602_gail_ omvedt-1.htm.

31 Walter Brueggemann, Money and Possessions (Louisville: Westminster John Knox, 2016); see also Kathryn Tanner, Christianity and the New Spirit of Capitalism (New Haven: Yale University Press, 2018).

32 For a more comprehensive discussion on the history of the beginnings of liberation theology, see also Ulrich Duchrow's Chapter 5 in this volume.

33 Paul E. Sigmund, The Birth of Liberation Theology: Medellin and Beyond (Oxford: Oxford University Press, 1992), 30; Christopher Rowland, ed., Cambridge Companion to Liberation Theology (Cambridge: Cambridge University Press, 1999); Leonardo Boff and Clodovis Boff, Introducing Liberation Theology (Kent, UK: Burns and Oats, 1987).

34 Sigmund, The Birth of Liberation Theology, 28.

35 Although the kernel of the movement was sown in the Catholic church and by the priests in Latin America, the distinctive development that included the reading of God's inclusive justice and acts on behalf of the oppressed has a Protestant dimension, as highlighted by Brian Stanley. See Brian Stanley, Christianity in the Twentieth Century: A Global History (Princeton: Princeton University Press, 2018), 237-38.

36 Jay Corrin, “The English Catholic New Left and Liberation Theology," Journal of Church and State 59, no. 1 (2017): 43-58, doi:10.1093/jcs/csv090.

37 Leonardo Boff, Come, Holy Spirit: Inner Fire, Giver of Life and Comforter of the Poor (Maryknoll, NY: Orbis Books, 2015), 3-4.

38 Boff and Boff, Introducing Liberation Theology, 1.

39 Ibid., 3.

40 Ibid.

41 Ibid., 5.

42 Rowland, ed., Cambridge Companion to Liberation Theology, 2.

43 While liberation theology inspired theologies of liberation in other local contexts, the second stage of liberation theology also saw critical interventions, particularly from feminist theologians incorporating more wide-ranging identities of marginality including LGBTQ; see Marcella Althaus-Reid, From Feminist Theology to Indecent Theology: Readings on Poverty, Sexuality Identity and God (London: SCM, 2004).

44 Rowland, Cambridge Companion to Liberation Theology, 250.

45 Norman Etherington, Mission and Empire (Oxford: Oxford University Press, 2008); Brian Stanley, “'Commerce and Christainity': Providence Theory, the Missionary Movement, and the Imperialism of Free Trade," The Historical Journal 26, no. 1 (1983): 71-94. Drawing from the context of the Tswana of South Africa, the complex relationship between Christian mission and the introduction of market economy is astutely discussed by the anthropologists Jean Comaroff and John Comaroff, Of Revelation and Revolution: Christianity, Colonialism, and Consciousness, vol. 1 (Chicago, IL: The University of Chicago Press, 1991), 165-71. The critique of collusion between Christian mission and imperial power is more complex; for a judicious discussion of the theme, see David Bosch, Transforming Mission: Paradigm Shifts in Theology of Mission (Maryknoll, NY: Orbis Books, 1991), 302-12. The dynamics of Christian mission and the transformation it wrought were wide-ranging, as were the missionaries and their home bases; see David A. Hollinger, Protestants Abroad: How Missionaries 
Tried to Change the World but Changed America (Princeton, NJ: Princeton University Press, 2017), 3.

46 Brian Stanley, Christian Missions and the Enlightenment (Grand Rapids, MI: Eerdmans, 2004), 8.

47 For a resourceful discussion on the dynamics of Christian mission and its project of establishing Christianity in the country, see Robert Eric Frykenberg, Christianity in India: From Beginnings to the Present (New Delhi: Oxford University Press, 2008).

48 For instance, the Presbyterian mission, as part of which Sam Higginbotham contributed to the establishment of the Agriculture University; for discussion of this, see Hollinger, Protestants Abroad. See also Felix Wilfred, "What Is Wrong with Rice-Christians? Wellbeing as Salvation: A Subaltern Perspective," Third Millennium IV (2001): 6-18, 6-8.

49 For more details, see Mrinalini Sebastian, "Localised Cosmopolitanism and Globalised Faith: Echoes of 'Native' Voices in Eighteenth- and Nineteenth-Century Missionary Documents," in European Missions in Contact Zones: Transformation through Interaction, ed. Judith Becker (Gottingen: Vandenhoeck and Ruprecht, 2015), 47-64; see also Albrecht Frenz, Freiheit has Gesicht: Anandapur, eine Begegnung Zwischen Kodagu und Baden-Wurttemberg (Stuttgart: Staatsanzeigler fur Baden-Wurttemberg, 2003).

50 Stanley, Christianity in the Twentieth Century.

51 See Eliza F. Kent, Converting Women: Gender and Protestant Christianity in Colonial South India (New York: Oxford University Press, 2004), 150-53.

52 Quoted in Kendal P. Mobley, Helen Barrett Montgomery: The Global Mission of Domestic Feminism (Waco, TX: Baylor University Press, 2009), 13.

53 For a discussion on the beginnings of women's higher education and professionalisation in India, see Maina Chawla Singh, Gender, Religion, and the Heathen Lands: American Missionary Women in South Asia, 1860s-1940s (New York: Taylor and Francis, 2000).

54 C. René Padilla, "The Globalization of Solidarity," Journal of Latin American Theology 9, no. 2 (2004): 69-90.

55 See Michael Barram, Missional Economics: Biblical Justice and Christian Formation (Grand Rapids, MI: Eerdmans, 2018), 120.

56 Ibid., 122.

57 Ibid.

58 Ibid., 127.

59 G. Gutiérrez, “The Task and Content of Liberation Theology," translated by Judith Condor, in Cambridge Companion to Liberation Theology, ed. Christopher Rowland (Cambridge: Cambridge University Press, 1999), 33.

60 Ibid., 34.

61 Sölle, Political Theology, 67.

62 Ibid.

63 Ibid., 83.

64 In the context of the financial crisis of 2008 in the United States, Matthew A. Shadle draws on Catholic social thought to renew the theological tasks of working for a just society; see Matthew A. Shadle, Interrupting Capitalism: Catholic Social Thought and the Economy (Oxford: Oxford University Press, 2018), 4.

65 Shadle, Interrupting Capitalism, 158.

66 For pioneering tribal theologies, see Nirmal Minz, "Religion, Culture, and Education in the Context of Tribal Aspirations in India," Journal of Dharma 24, no. 4 (1999): 402-16; Wati Longchar, Tribal Theology: An Emerging Asian Theology: Issue, Method and Perspective (Jorhat, India: ETC Publications, 2000).

67 Wilfred, Margins: Site of Asian Theologies, 61. 
68 Shadle, Interrupting Capitalism, 20.

69 In a daily reflection of the Centre for Contemplative Action, Richard Rohr highlighted an understanding of mysticism that is not otherworldly but a realisation of a responsible relationship with the whole of creation, using the following words from Beverly Lanzetta: "Mysticism also refers to a universal and unifying view of the world. One of the quintessential insights of the mystics through the centuries is that the entire cosmos is intersubjective - all beings are embedded in webs of relationship that are interconnected, interdependent. . . . Today, mystical awareness expands to incorporate our relationships, and . . . the whole of humanity, creation ... the suffering of the planet, ... and violence caused by religious superiority, national self-interest, poverty, homelessness, starvation, and war". See https://cac.org/living-mysticism-2019-08-07/, accessed November 11, 2019.

70 Sölle, Silent Cry, 151.

71 Ibid., 138-41.

72 Ibid., 149.

73 Johnson, Abounding in Kindness, 7.

74 Shadle, Interrupting Capitalism, 21.

75 Johnson, Abounding in Kindness, 7.

76 Quoted in Christopher Rowland and J. Sobrino, Companions of Jesus: The Murder and Martyrdom of the Salvadorean Jesuits (London: CIIR/CAPOD, 1990), $50-51$.

77 Sölle, The Silent Cry, 4.

78 Johnson, Abounding in Kindness, 13. 